\title{
Language extinction triggers the loss of unique medicinal knowledge
}

\author{
Rodrigo Cámara-Leret* \& Jordi Bascompte \\ Department of Evolutionary Biology and Environmental Studies, \\ University of Zurich, 8057 Zurich, Switzerland \\ * Correspondence: rodrigo.camaraleret@ieu.uzh.ch
}

December 3, 2020

\begin{abstract}
There are nearly 7,400 languages in the world and over $30 \%$ of these will no longer be spoken by the end of the century ${ }^{1}$. So far, however, our understanding of whether language extinction may result in the loss of linguistically-unique knowledge remains limited. Here, we ask to what degree indigenous knowledge of medicinal plants is associated to individual languages and quantify how much indigenous knowledge may vanish as languages and plants go extinct. Focussing on three independent regions that have a high biocultural diversity - North America, northwest Amazonia, and New Guinea - we show that $>75 \%$ of all 12,495 medicinal plant services are linguistically-unique, i.e., only known to one language. Whereas most plant species associated with linguistically-unique knowledge are not threatened, most languages that report linguistically-unique knowledge are. Our finding of high uniqueness in indigenous knowledge and strong coupling with threatened languages suggests that language loss will be even more critical to the extinction of medicinal knowledge than biodiversity loss.
\end{abstract}


Indigenous people have accumulated a sophisticated knowledge about plants and their services -including knowledge that confers significant health benefits ${ }^{2}$ - that is encoded in their languages ${ }^{3}$. Indigenous knowledge, however, is increasingly threatened by language loss and species extinctions ${ }^{4,5}$. On one hand, language disuse is strongly associated 5 to decreases in indigenous knowledge about plants ${ }^{6}$. On the other hand, global change will constrain the geographic ranges of many human-utilized endemic plants and $\operatorname{crops}^{7,8}$. Together, language extinction and reductions in useful plant species within the coming century may limit the full potential of nature's contributions to people and the discovery of unanticipated uses ${ }^{9}$. So far, however, our understanding of the degree to which the loss of indigenous languages may result in the loss of linguistically-unique knowledge and how this risk compares to that posed by ecological extinction has been limited (Fig. 1).

Unravelling the structure of indigenous knowledge about medicinal services has important implications for its resilience ${ }^{10}$. Most indigenous cultures transmit knowledge orally ${ }^{11}$. Therefore, if knowledge about medicines is shared widely amongst indigenous groups that speak different languages, knowledge resilience would be high. That is, even if some indigenous languages go extinct, their medicinal plant knowledge would still be safeguarded in other surviving languages with whom such knowledge is shared. To assess the extent of this, we analyzed three large ethnobotanical datasets for North America ${ }^{12}$, northwest Amazonia $^{13}$, and New Guinea ${ }^{14}$. Together, these data span 3,597 medicinal plant species, and 12,495 plant services associated to 236 indigenous languages (see Methods). We defined a 'medicinal plant service' as the combination of a plant species and a medicinal subcategory (e.g., Ficus insipida + Digestive System).

Our results show that in all regions, indigenous knowledge about medicinals plants exhibits a strong pattern of linguistic uniqueness, with $73 \%, 91 \%$, and $84 \%$ of the medicinal services in North America, northwest Amazonia, and New Guinea being cited by only one language, respectively (Fig. 2). This finding raises the question of whether unique knowledge is mostly found in languages that are threatened.

Our analysis indicates that threatened languages support $82 \%$ and $66 \%$ of all unique knowledge in North America and northwest Amazonia, respectively (Supplementary Fig. 1). By contrast, threatened languages account for only $18 \%$ of all unique knowledge in New Guinea. This result highlights that the Americas are an indigenous knowledge hotspot (i.e., most medicinal knowledge is linked to threatened languages), and thus a key priority area for future documentation efforts.

Once we have quantified the overall amount of unique knowledge, we next proceed by mapping how it is distributed across the linguistic phylogeny. This will serve to identify whether unique knowledge is uniformly distributed across all linguistic groups, or whether a few linguistic groups deserve more protection than others. First, we built language 
phylogenies for all the indigenous languages in our sample. Next, we calculated the degree of phylogenetic clustering of unique knowledge using Pagel's lambda $(\lambda)^{15}$; values of $\lambda$ close to 1 indicate strong phylogenetic clustering, whereas values close to 0 indicate data without phylogenetic dependence. We did not find clustering of unique knowledge along the language phylogenies in any of the three regions (Fig. 3, Extended Data Table 1). This indicates that when planning for medicinal knowledge conservation, the entire linguist spectrum — rather than a few "hot" nodes - needs to be considered.

So far, we have focused on how unique knowledge is distributed along the cultural dimension. Let us turn now to examine the other component of the indigenous knowledge network, namely the plants. To understand the degree of threat faced by medicinal plants, we queried the IUCN Red List of Threatened species ${ }^{16}$. We found conservation assessments for $22 \%, 31 \%$ and $32 \%$ of the medicinal species recorded in North America, northwest Amazonia, and New Guinea, respectively. Of the total medicinal flora with IUCN assessments, 4\%, 1\%, and 4\% were classified as threatened in North America, northwest Amazonia, and New Guinea, respectively (see Methods). To ascertain whether the observed patterns may change as more species are formally assessed, we also obtained conservation predictions from a machine-learning study ${ }^{17}$ (see Methods) which contains assessments for $57 \%, 25 \%$, and $49 \%$ of the medicinal species recorded in North America, northwest Amazonia, and New Guinea, respectively. According to that study, the probability of a medicinal species belonging to a threatened category ranged from 0.0002 to 0.8341 in North America (mean $\pm \mathrm{SD}, 0.156 \pm 0.158$ ), 0.149 to 0.822 in northwest Amazonia (mean $0.483 \pm 0.119$ ), and 0.063 to 0.679 in New Guinea (mean $0.357 \pm 0.141$ ), respectively. In summary, both the IUCN conservation assessments and machine-learning predictions suggest that most medicinal plant species in our sample are not threatened. Finally, we found that less than $1 \%$ of all unique knowledge in each region was associated to both threatened languages and threatened plants (Extended Data Table 3). However, there is considerable uncertainty about the potential loss of unique knowledge from the extinction of plants because $61 \%$ and $46 \%$ of the unique knowledge in North America and northwest Amazonia that is associated to threatened languages belongs to plants that lack plant conservation assessments. IUCN conservation assessments are urgently needed for these plant species.

To assess whether unique knowledge is strongly clustered biologically, we built phylogenies the medicinal floras of each region, and calculated Pagel's lambda (Fig. 4). We only found significant clustering of unique knowledge in North America, although values were low (Extended Data Table 1). This relatively weak phylogenetic signal across the three regions suggests that when planning for biocultural conservation, the entire medicinal flora - rather than a few clades - must be considered. 
Here, we have shown that in North America, northwest Amazonia, and New Guinea, indigenous knowledge of medicinal plant services exhibits a low redundancy across languages that is typical of systems with high information content ${ }^{18,19}$. This low redundancy in medicinal knowledge among languages does not support the notion of high cross-cultural consensus, i.e., that cultures resemble each other in their knowledge, but instead highlights the unique biocultural heritage each culture holds. The invention and diversification of languages involves two opposing forces. On the one hand, sharing facilitates the exchange of information and the spread of valuable ideas that may enhance the fitness within populations. On the other hand, the diversification of languages is the result of innovations, and eventually linguistic barriers may limit information spread. In areas of high linguistic or biological diversity, and/or geographic barriers, the balance between sharing and innovating may tip towards the latter. This may result in the amplification of differences among cultures, as we have shown here for the case of medicinal knowledge.

The United Nations declared 2019 as the year of the world's Indigenous languages to raise awareness of their endangerment across the world. Our study suggest that each indigenous language brings unique insights that may be complementary to other societies who seek potentially-useful medicinal remedies. Therefore, the predicted extinction of up to $30 \%$ of indigenous languages by the end of the 21 st century ${ }^{1}$ would substantially compromise humanity's capacity for medicinal discovery. 


\section{Methods}

Plant Services. We obtained a list of medicinal plant species and services associated to individual indigenous groups from three regions: 1) North America: from the Native American Ethnobotany database ${ }^{12}$ - the largest repository of indigenous knowledge for the region; 2) northwest Amazonia: from Richard E. Schultes's book on the medicinal plants of northwestern Amazonia, which integrates nearly half a century of his field research $^{13}$; and 3) New Guinea: from an ethnobotanical review of 488 references and 854 herbarium specimens ${ }^{14}$.

We classified uses from the three data sources into medicinal subcategories following the classification in the Economic Botany Data Collection Standard ${ }^{20}$, with modifications explained by Cámara-Leret et $a ._{.}^{21}$. Medicinal subcategories included Blood and cardiovascular system; Cultural diseases and disorders; Dental health; Digestive system; Endocrine system; General ailments with unspecified symptoms; Infections and infestations; Metabolic system and nutrition; Muscular-skeletal system; Nervous system and mental health; Poisoning; Pregnancy, birth and puerperium; Reproductive system and reproductive health; Respiratory system; Sensory system; Skin and subcutaneous tissue; Urinary system; Veterinary; Not specified; Other medicinal uses. We defined 'unique knowledge' as a medicinal service cited exclusively by one indigenous language. By omitting 'plant parts' (e.g., bark, leaf, fruit, seed) from our definition of medicinal plant services (i.e.,the combination of plant species and a medicinal subcategory), our categorization is more conservative and underestimates the detection of medicinal knowledge that is restricted to one language.

Language Phylogenies and Threat. Medicinal services in the literature were associated to 119 indigenous languages in North America, 37 languages in northwest Amazonia, and 80 languages in New Guinea. For each region, we built language trees through phylogenetic inference using machine learning techniques on the word lists of the Automated Similarity Judgement Program (ASJP v.18) and used the Glottolog classification as a constraint tree ${ }^{22}$. To assess the degree of threat faced by languages in our sample, we queried the Ethnologue ${ }^{23}$ which uses the Expanded Graded Intergenerational Disruption Scale (EGIDS) to quantify language threat ${ }^{24}$. For a list of the languages analyzed, see Extended Data Table 2.

Vascular Plant Phylogenies and Threat. We verified plant species taxonomy using recently published checklists to the vascular plants of the Americas ${ }^{25}$ and New Guinea ${ }^{26}$. Using the list of medicinal plant species in each region, we queried the mega-tree GBOTB.extended of Smith \& Brown ${ }^{27}$ with the phylo.maker function of the $\mathrm{R}$ package V.PhyloMa$\operatorname{ker}^{28}$. The phylogenies used in all subsequent analyses comprised 2,475 species in North America, 645 species in northwest Amazonia, and 477 species in New Guinea. To assess 
the threat faced by medicinal plant species, we queried the conservation assessments published by the IUCN Red List of Threatened species ${ }^{16}$, which classifies species as Data Deficient, Least Concern, Near Threatened, Vulnerable, Endangered, and Critically Endangered, Extinct in the Wild, and Extinct. Following IUCN, species assessed to be Near Threatened, Vulnerable, and Endangered were considered threatened. Because most plant species lack IUCN conservation assessments, we also obtained endangerment probabilities from a recent study that used machine-learning to predict the conservation status of 30,497 plant species $^{17}$.

Acknowledgments. We thank G. Jäger for providing the language trees, the members of the Bascompte lab for helpful discussions, and I. Cámara Leret for the illustrations in Figs. 1 and 3.

Funding. Swiss National Science Foundation grant 310030_197201 to J. Bascompte.

Author Contributions. R. Cámara-Leret contributed to conceptualization, data collection, data analysis, writing - original draft, writing - review and editing; J. Bascompte contributed to conceptualization, writing - review and editing.

Competing interests. Authors declare no competing interests.

Supplementary Information is available for this paper as Extended Data Tables 1-3.

Correspondence and requests for materials should be addressed to:

Rodrigo Cámara-Leret, rodrigo.camaraleret@ieu.uzh.ch 


\section{References}

1. Simons, G. F. \& Lewis, M. P. in Responses to Language Endangerment 3-19 (John Benjamins Amsterdam, The Netherlands, 2013).

2. McDade, T. W. et al. Ethnobotanical knowledge is associated with indices of child health in the Bolivian Amazon. Proc. Natl Acad. Sci. USA 104, 6134-6139 (2007).

3. Berlin, B. Ethnobiological classification: Principles of Categorization of Plants and Animals in Traditional Societies (Princeton University Press, 2014).

4. Sutherland, W. J. Parallel extinction risk and global distribution of languages and species. Nature 423, 276-279 (2003).

5. Aswani, S., Lemahieu, A. \& Sauer, W. H. Global trends of local ecological knowledge and future implications. PLoS One 13, e0195440 (2018).

6. Saynes-Vásquez, A., Caballero, J., Meave, J. A. \& Chiang, F. Cultural change and loss of ethnoecological knowledge among the Isthmus Zapotecs of Mexico. J. Ethnobiol. Ethnomed. 9, 40 (2013).

7. Cámara-Leret, R. et al. Climate change threatens New Guinea's biocultural heritage. Sci. Adv. 5, eaaz1455 (2019).

8. Pironon, S. et al. Potential adaptive strategies for 29 sub-Saharan crops under future climate change. Nat. Clim. Change 9, 758-763 (2019).

9. Díaz, S. et al. Assessing nature's contributions to people. Science 359, 270-272 (2018).

10. Cámara-Leret, R., Fortuna, M. A. \& Bascompte, J. Indigenous knowledge networks in the face of global change. Proc. Natl Acad. Sci. USA 116, 9913-9918 (2019).

11. Nettle, D., Romaine, S., et al. Vanishing Voices: The Extinction of the World's Languages (Oxford University Press on Demand, 2000).

12. Moerman, D. Native American Ethnobotany: A Database of Foods, Drugs, Dyes and Fibers of Native American Peoples, Derived from Plants. 2020. http://naeb.brit.org/.

13. Schultes, R. E. \& Raffauf, R. F. The Healing Forest: Medicinal and Toxic Plants of the Northwest Amazonia. (Dioscorides Press, 1990).

14. Cámara-Leret, R. \& Dennehy, Z. Information gaps in indigenous and local knowledge for sciencepolicy assessments. Nat. Sustain. 2, 736-741 (2019).

15. Pagel, M. Inferring the historical patterns of biological evolution. Nature 401, 877-884 (1999).

16. IUCN. The IUCN Red List of Threatened Species. Version 2020-2. 2020. https://www. iucnredlist . org/accessed2020-05-08.

17. Pelletier, T. A., Carstens, B. C., Tank, D. C., Sullivan, J. \& Esprándola, A. Predicting plant conservation priorities on a global scale. Proc. Natl Acad. Sci. USA 115, 13027-13032 (2018).

18. Shannon, C. E. A mathematical theory of communications. Bell Syst. Tech. J 27, 379-423 (1948).

19. Margalef, R. Information theory in biology. Gen. Syst. 3, 36-71 (1958).

20. Cook, F. E. et al. Economic Botany Data Collection Standard. (Royal Botanic Gardens (Kew), 1995).

21. Cámara-Leret, R., Paniagua-Zambrana, N., Balslev, H. \& Macía, M. J. Ethnobotanical knowledge is vastly under-documented in northwestern South America. PLoS One 9, e85794 (2014). 
22. Jäger, G. Global-scale phylogenetic linguistic inference from lexical resources. Sci. Data 5, 1-16 (2018).

23. Simons, G. F. \& Fennig, C. D. Ethnologue: Languages of the World, 21st Edn Dallas. TX: SIL International (2018).

24. Lewis, M. P. \& Simons, G. F. Assessing endangerment: expanding Fishman's GIDS. Rev. Roum. de Linguistique 55, 103-120 (2010).

25. Ulloa, C. U. et al. An integrated assessment of the vascular plant species of the Americas. Science 358, 1614-1617 (2017).

26. Cámara-Leret, R. et al. New Guinea has the world's richest island flora. Nature 584, 579-583 (2020).

27. Smith, S. A. \& Brown, J. W. Constructing a broadly inclusive seed plant phylogeny. Am. J. Bot. 105, 302-314 (2018).

28. Jin, Y. \& Qian, H. V. PhyloMaker: an R package that can generate very large phylogenies for vascular plants. Ecography 42, 1353-1359 (2019). 


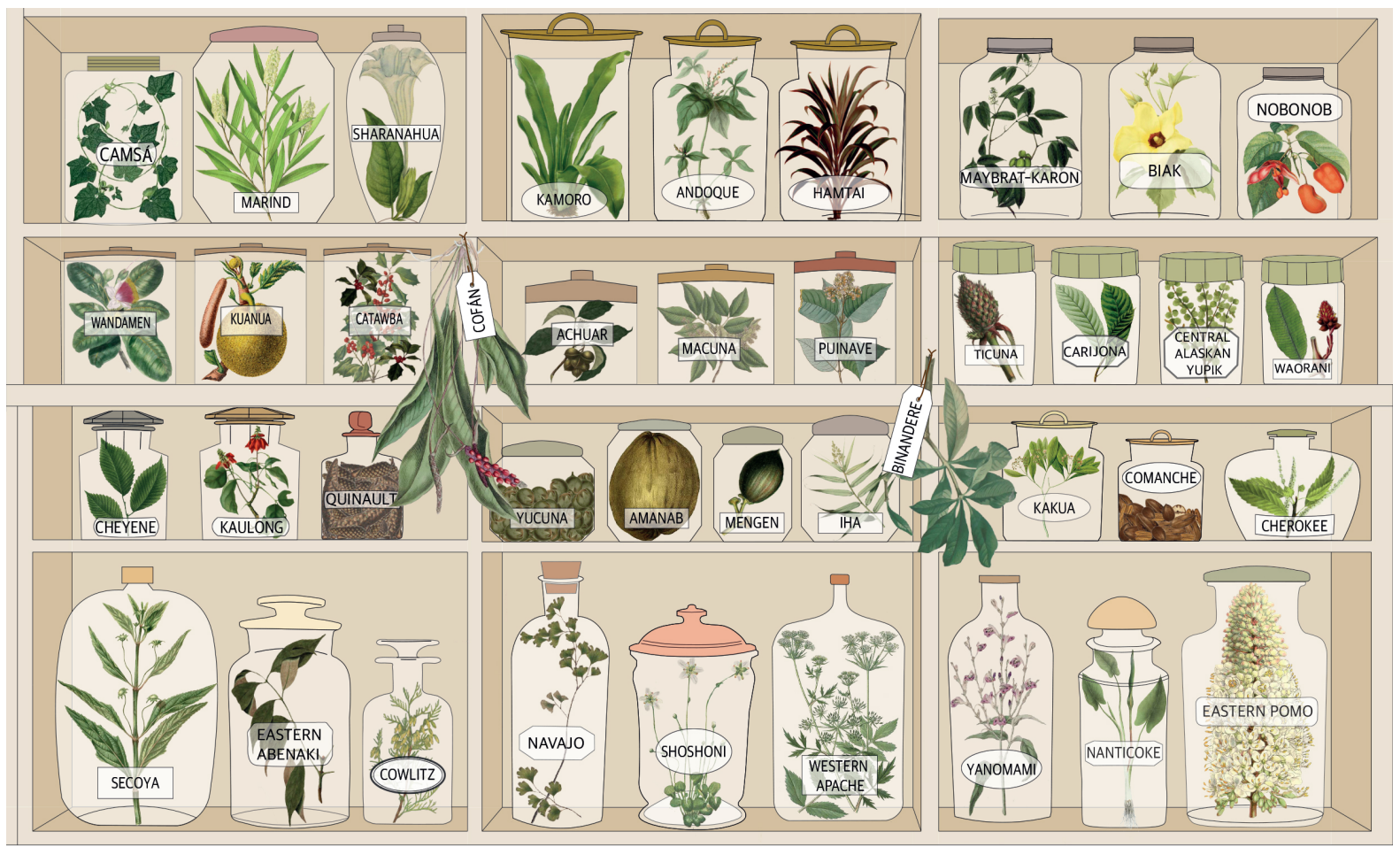

Fig. 1 | Medicinal plant knowledge and its association to indigenous languages. The figure illustrates a regional pharmacy with remedies (jars with plants) cited by languages (jar labels). In this paper, we assess to what degree the knowledge contained in this pharmacy would be eroded by the extinction of either indigenous languages or plants. 

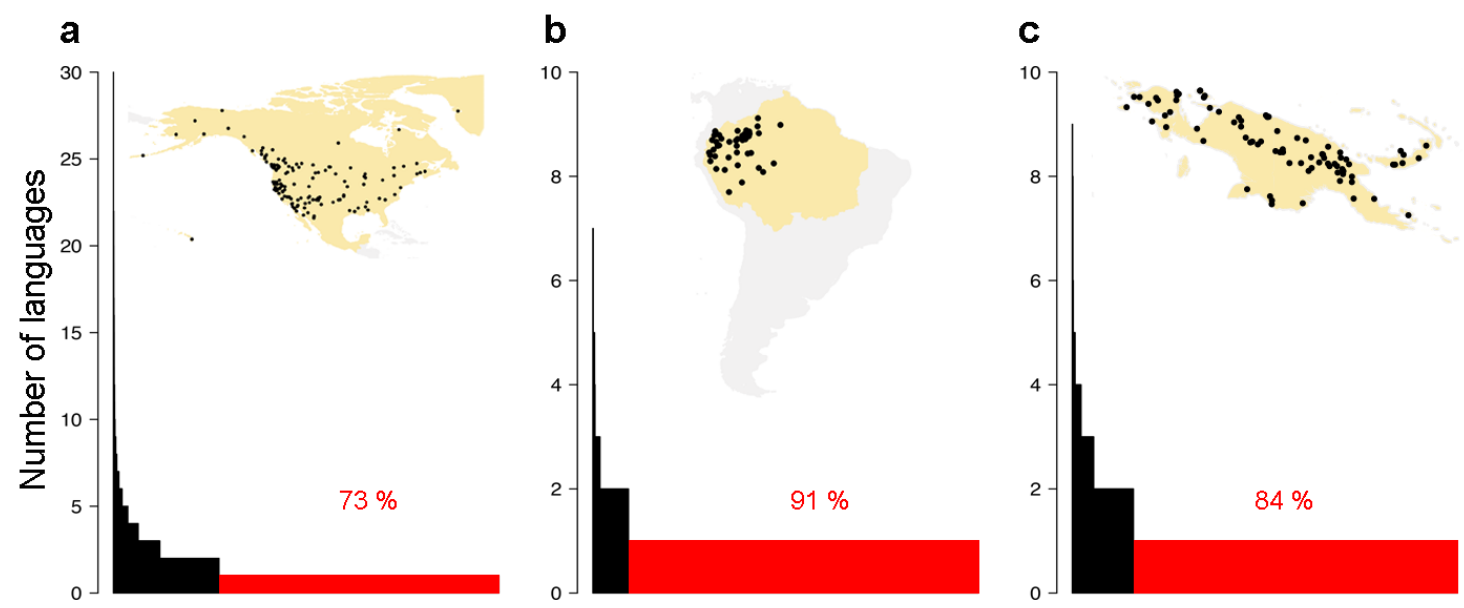

Medicinal services

Fig. 2 | Most medicinal knowledge is unique to a single language. Histograms depict the number of indigenous languages that cite a medicinal service. a, North America; b, northwest Amazonia; c, New Guinea. Red bars show medicinal plant services only known to one language. Dots within the maps indicate the distribution of languages. 

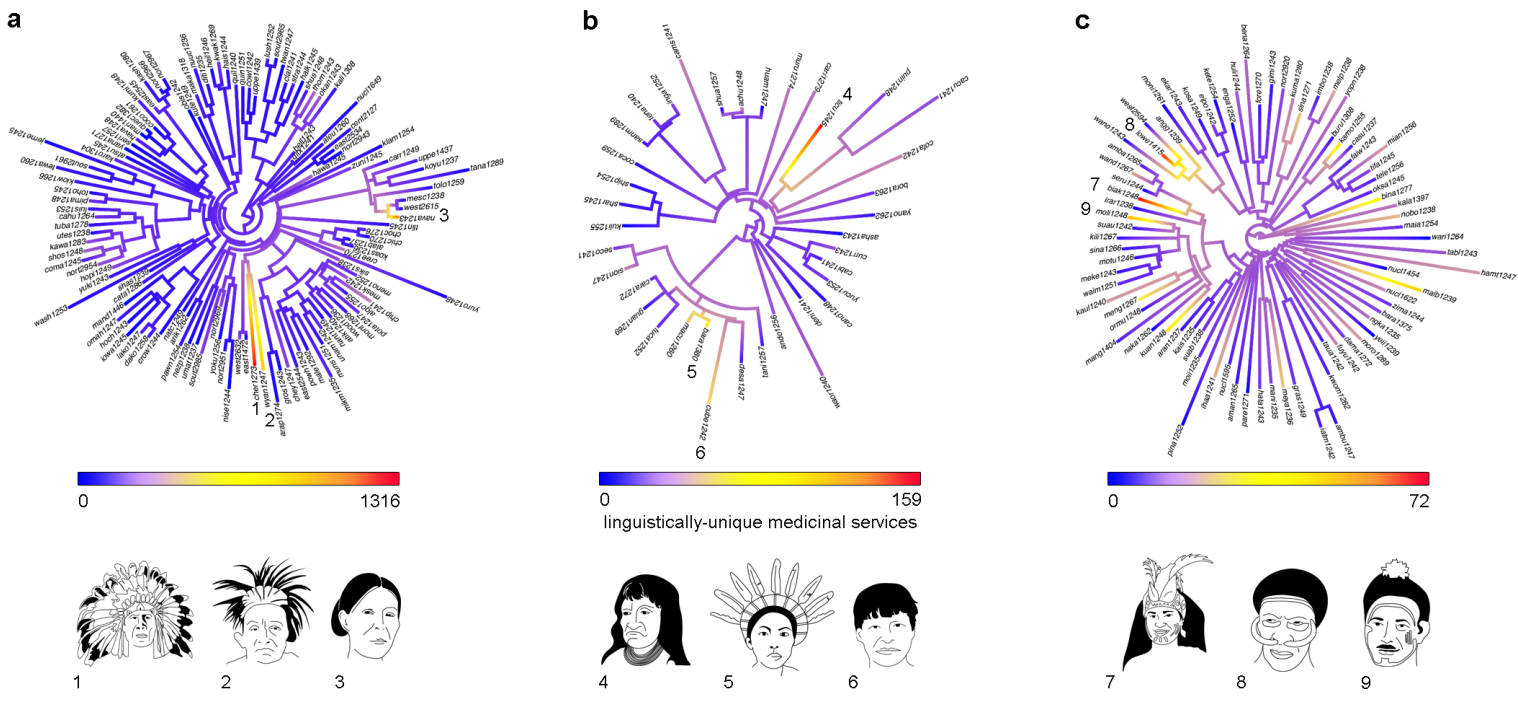

Fig. 3 | Distribution of unique knowledge across languages. Trees represent lan-

guage phylogenies of a, North America ( $n=119$ languages); b, northwest Amazonia ( $n$ $=37$ languages); and c, New Guinea ( $n=80$ languages). Illustrations represent indigenous groups whose languages have the highest number of unique medicinal services per region. These languages are indicated by their corresponding numbers in the linguistic trees: 1, Cherokee; 2, Iroquois; 3, Navajo; 4, Tikuna; 5, Barasana; 6, Cubeo; 7, Biak; 8, Lower Grand Valley Dani; 9, Massim. Language names at phylogeny tips are abbreviated following Glottolog codes. For the list of language names and Glottolog codes, see Extended Data Table 2. 

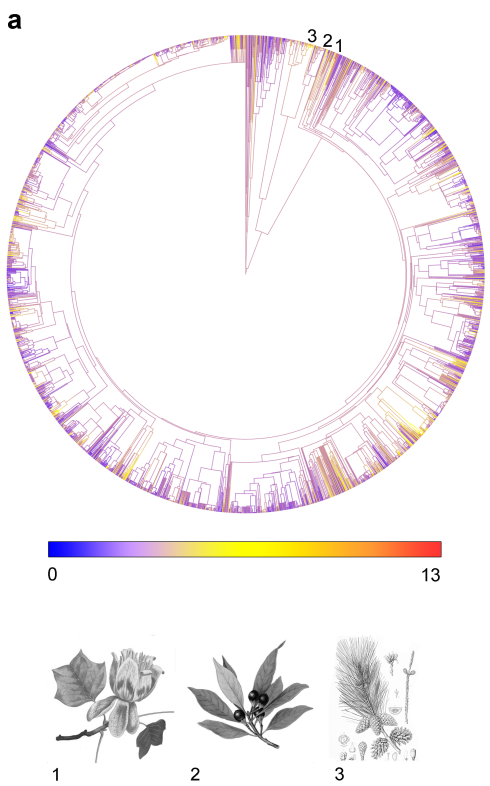

b
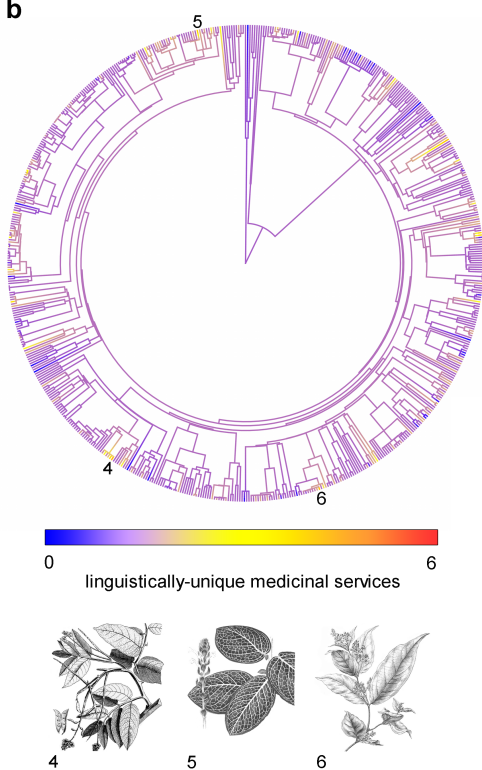
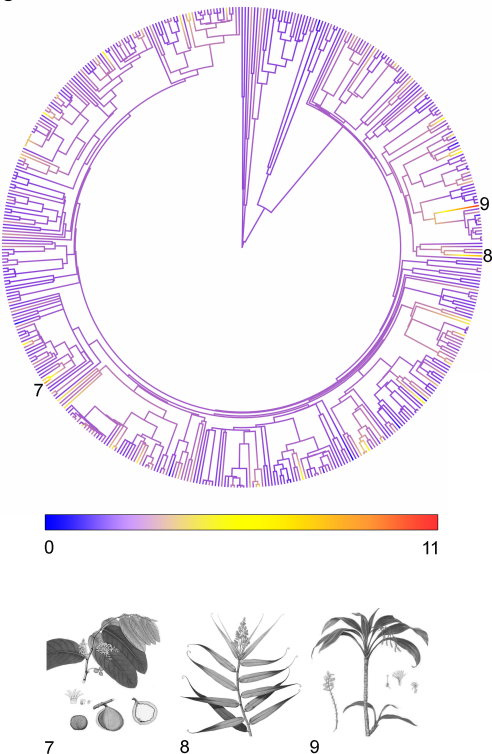

Fig. 4 | Distribution of unique knowledge across medicinal floras. Trees represent medicinal plant phylogenies of $\mathbf{a}$, North America ( $n=2,475$ species); $\mathbf{b}$, northwest Amazonia ( $n=645$ species); and $\mathbf{c}$, New Guinea ( $n=477$ species). Illustrations and their corresponding numbers show the plant species with more unique medicinal services per region. 1, Liriodendron tulipifera; 2, Persea borbonia; 3, Pinus glabra; 4, Tachigali paniculata; 5, Fittonia albivenis; 6, Tetrapterys styloptera; 7, Inocarpus fagifer; 8, Flagellaria indica; 9, Cordyline fruticosa. All illustrations from http://www.plantillustrations.org belong to the public domain. 
Extended Data Table 1 | Phylogenetic clustering (measured using Pagel's $\lambda$ ) of unique knowledge along the language and plant phylogenies of North America, Northwest Amazonia, and New Guinea. Statistically significant results: $* * *, \mathrm{P}$-value $<0.001$.

\begin{tabular}{lll}
\hline & Languages & Plants \\
\hline North America & 0.31 & $0.21^{* * *}$ \\
Northwest Amazonia & $6.61 \mathrm{e}-05$ & $6.61 \mathrm{e}-05$ \\
New Guinea & $6.61 \mathrm{e}-05$ & 0.02 \\
\hline
\end{tabular}


Extended Data Table 2 | Names and Glottolog codes of the studied languages of North America, northwest Amazonia, and New Guinea.

\begin{tabular}{|c|c|}
\hline Language name & Glottolog code \\
\hline \multicolumn{2}{|l|}{ NORTH AMERICA } \\
\hline Alabama & alab1237 \\
\hline Aleut & aleu1260 \\
\hline Algonquin & algo1255 \\
\hline Arapaho & $\operatorname{arap} 1274$ \\
\hline Arikara & $\operatorname{arik1262}$ \\
\hline Atikamekw & atik1240 \\
\hline Atsugewi & atsu1245 \\
\hline Bella Coola & bell1243 \\
\hline Cahuilla & cahu1264 \\
\hline Central Carrier & carr1249 \\
\hline Catawba & cata1286 \\
\hline Central Alaskan Yupik & cent 2127 \\
\hline Cherokee & cher 1273 \\
\hline Cheyenne & chey 1247 \\
\hline Chickasaw & $\operatorname{chic} 1270$ \\
\hline Chippewa & chip1241 \\
\hline Choctaw & choc1276 \\
\hline Clallam & clal1241 \\
\hline Cocopa & $\operatorname{coco} 1261$ \\
\hline Comanche & coma1245 \\
\hline Cowlitz & cowl1242 \\
\hline Creek & cree 1270 \\
\hline Crow & crow1244 \\
\hline Dakota & dako1258 \\
\hline Ditidaht & $\operatorname{diti1} 235$ \\
\hline Eastern Keres & east1472 \\
\hline Eastern Canadian Inuktitut & east 2534 \\
\hline Eastern Abenaki & east 2544 \\
\hline Eastern Pomo & east2545 \\
\hline Gitxsan & gitx1241 \\
\hline Gros Ventre & $\operatorname{gros} 1243$ \\
\hline Haisla & hais1244 \\
\hline Halkomelem & halk1245 \\
\hline Havasupai-Walapai-Yavapai & hava1248 \\
\hline Hawaiian & hawa1245 \\
\hline Heiltsuk-Oowekyala & heil1246 \\
\hline Ho-Chunk & hoch 1243 \\
\hline Hopi & hopi1249 \\
\hline Iowa-Oto & iowa1245 \\
\hline Towa & jeme1245 \\
\hline Kalispel-Pend d'Oreille & kali1308 \\
\hline Karok & karo1304 \\
\hline Kashaya & $\operatorname{kash} 1280$ \\
\hline
\end{tabular}


bioRxiv preprint doi: https://doi.org/10.1101/2020.12.03.407593; this version posted December 3, 2020. The copyright holder for this preprint (which was not certified by peer review) is the author/funder, who has granted bioRxiv a license to display the preprint in perpetuity. It is made available under aCC-BY 4.0 International license.

Extended Data Table 2. (continued)

\begin{tabular}{|c|c|}
\hline Language name & Glottolog code \\
\hline \multicolumn{2}{|l|}{ NORTH AMERICA } \\
\hline Kawaiisu & kawa1283 \\
\hline Kiowa & kiow1266 \\
\hline Klamath-Modoc & klam1254 \\
\hline Koasati & koas1236 \\
\hline Koyukon & koyu 1237 \\
\hline Tipai & kumi1248 \\
\hline Kutenai & kute1249 \\
\hline Kwak'wala & kwak1269 \\
\hline Lakota & lako1247 \\
\hline Luiseno-Juaneño & luis 1253 \\
\hline Northern Lushootseed & lush 1252 \\
\hline Makah & maka1318 \\
\hline Malecite-Passamaquoddy & male1292 \\
\hline Mandan & mand 1446 \\
\hline Maricopa & mari1440 \\
\hline Menominee & meno1252 \\
\hline Mescalero-Chiricahua Apache & $\operatorname{mesc} 1238$ \\
\hline Meskwaki & mesk1242 \\
\hline Mi'kmaq & mikm1235 \\
\hline Montagnais & mont 1268 \\
\hline Munsee & muns 1251 \\
\hline Nanticoke & nant1249 \\
\hline Natchez & natc1249 \\
\hline Navajo & nava1243 \\
\hline Nez Perce & nezp1238 \\
\hline Nisenan & nise 1244 \\
\hline North Alaskan Inupiatun & nort 2943 \\
\hline Northwest Maidu & nort2951 \\
\hline Northern Paiute & nort 2954 \\
\hline Northern Pomo & nort2966 \\
\hline Northeastern Russian River Pomo & nort 2967 \\
\hline Northern Ohlone & nort 2969 \\
\hline Southern-Coastal Tsimshian & nucl1649 \\
\hline Nuu-chah-nulth & nuuc1236 \\
\hline Obispeño & obis 1242 \\
\hline Okanagan & okan1243 \\
\hline Omaha-Ponca & omah1247 \\
\hline Pawnee & pawn1254 \\
\hline Pima Bajo & pima1248 \\
\hline Potawatomi & $\operatorname{pota} 1247$ \\
\hline Powhatan & powh1243 \\
\hline Quechan & quec1382 \\
\hline Quileute & quil1240 \\
\hline Quinault & quin1251 \\
\hline Seri & seri1257 \\
\hline
\end{tabular}


bioRxiv preprint doi: https://doi.org/10.1101/2020.12.03.407593; this version posted December 3, 2020. The copyright holder for this preprint (which was not certified by peer review) is the author/funder, who has granted bioRxiv a license to display the preprint in perpetuity. It is made available under aCC-BY 4.0 International license.

Extended Data Table 2. (continued)

\begin{tabular}{ll}
\hline Language name & Glottolog code \\
\hline NORTH AMERICA & shas1239 \\
Shasta & shos1248 \\
Shoshoni & shus1248 \\
Shuswap & siks1238 \\
Siksika & sout2961 \\
Southern Tiwa & sout2965 \\
Southern Puget Sound Salish & sout2985 \\
Southern Sierra Miwok & stra1244 \\
Northern Straits Salish & tana1289 \\
Tanaina & tewa1260 \\
Rio Grande Tewa & thom1243 \\
Thompson & tlin1245 \\
Tlingit & toho1245 \\
Tohono O'odham & tolo1259 \\
Tolowa-Chetco & tuba1278 \\
Tubatulabal & twan1247 \\
Twana & umat1237 \\
Umatilla & unam1242 \\
Unami & uppe1437 \\
Upper Tanana & uppe1439 \\
Upper Chehalis & utes1238 \\
Ute-Southern Paiute & wash1253 \\
Washo & west2615 \\
Western Apache & west2632 \\
Western Keres & wood1236 \\
Woods Cree & wyan1247 \\
Huron-Wyandot & yana1271 \\
Yana & yoku1256 \\
Northern Yokuts & yuki1243 \\
Yuki & yuro1248 \\
Yurok & zuni1245 \\
Zuni & \\
\hline & \\
&
\end{tabular}


bioRxiv preprint doi: https://doi.org/10.1101/2020.12.03.407593; this version posted December 3, 2020. The copyright holder for this preprint (which was not certified by peer review) is the author/funder, who has granted bioRxiv a license to display the preprint in perpetuity. It is made available under aCC-BY 4.0 International license.

Extended Data Table 2. (continued)

\begin{tabular}{ll}
\hline Language name & Glottolog code \\
\hline NORTHWEST AMAZONIA & \\
Achuar-Shiwiar & achu1248 \\
Andoque & ando1256 \\
Asháninka & asha1243 \\
Barasana-Eduria & bara1380 \\
Bora & bora1263 \\
Cabiyari & cabi1241 \\
Kakua & cacu1241 \\
Camsá & cams1241 \\
Candoshi-Shapra & cand1248 \\
Carapana & cara1272 \\
Carijona & cari1279 \\
Cocama-Cocamilla & coca1259 \\
Cofán & cofa1242 \\
Cubeo & cube1242 \\
Curripaco & curr1243 \\
Deni & deni1241 \\
Desano & desa1247 \\
Kotiria & guan1269 \\
Huambisa & huam1247 \\
Inga & inga1252 \\
Kulina Pano & kuli1255 \\
Macuna & macu1260 \\
Murui Huitoto & muru1274 \\
Puinave & puin1248 \\
San Martín Quechua & sanm1289 \\
Secoya & seco1241 \\
Sharanahua & shar1245 \\
Shipibo-Conibo & ship1254 \\
Shuar & shua1257 \\
Siona-Tetete & sion1247 \\
Tanimuca-Retuarã & teni1257 1240 \\
Tena Lowland Quichua & ticu1245 \\
Ticuna & tuca1252 \\
Tucano & waor1240 \\
Waoorani & yano1262 1253 \\
Yanomámi & \\
Yucuna & \\
\hline
\end{tabular}


bioRxiv preprint doi: https://doi.org/10.1101/2020.12.03.407593; this version posted December 3, 2020. The copyright holder for this preprint (which was not certified by peer review) is the author/funder, who has granted bioRxiv a license to display the preprint in perpetuity. It is made available under aCC-BY 4.0 International license.

Extended Data Table 2. (continued)

\begin{tabular}{ll}
\hline Language name & Glottolog code \\
\hline NEW GUINEA & aman1265 \\
Amanab & amba1265 \\
Ambai & ambu1247 \\
Ambulas & angg1239 \\
Angguruk Yali & aran1237 \\
Dombano & bara1375 \\
Barapasi & bena1264 \\
Benabena & biak1248 \\
Biak & bina1277 \\
Binandere & buru1308 \\
Buruwai & casu1237 \\
Casuarina Coast Asmat & dama1272 \\
Damal & eipo1242 \\
Eipomek & ekar1243 \\
Ekari & enga1252 \\
Enga & faiw1243 \\
Faiwol & fore1270 \\
Fore & fuyu1242 \\
Fuyug & gimi1243 \\
Gimi (Eastern Highlands) & gras1249 \\
Grass Koiari & hamt1247 \\
Hamtai & hata1243 \\
Hatam & huli1244 \\
Huli & iatm1242 \\
Iatmul & ihaa1241 \\
Iha & imbo1238 \\
Imbongu & irar1238 \\
Irarutu & kais1235 \\
Kais & kala1397 \\
Kalam & kamo1255 \\
Kamoro & kaul1240 \\
Kaulong & kete1254 \\
Ketengban & kosa1249 \\
Kilivila & kuan1248 \\
Kosarek Yale & kwom1262 \\
Kuanua & \\
Kuman & \\
Kwoma & \\
\hline
\end{tabular}


bioRxiv preprint doi: https://doi.org/10.1101/2020.12.03.407593; this version posted December 3, 2020. The copyright holder for this preprint (which was not certified by peer review) is the author/funder, who has granted bioRxiv a license to display the preprint in perpetuity. It is made available under aCC-BY 4.0 International license.

Extended Data Table 2. (continued)

\begin{tabular}{|c|c|}
\hline Language name & Glottolog code \\
\hline \multicolumn{2}{|l|}{ NEW GUINEA } \\
\hline Lower Grand Valley Dani & lowe 1415 \\
\hline Maia & maia1254 \\
\hline Maybrat-Karon & maib1239 \\
\hline Mangga Buang & mang1404 \\
\hline Sougb & $\operatorname{mani} 1235$ \\
\hline Mekeo & meke1243 \\
\hline Melpa & melp1238 \\
\hline Mengen & meng1267 \\
\hline Meyah & meya 1236 \\
\hline Mian & $\operatorname{mian} 1256$ \\
\hline Moi (Indonesia) & moii1235 \\
\hline Molima & $\operatorname{moli1} 1248$ \\
\hline Moni & moni1261 \\
\hline Marori & moro1289 \\
\hline Motu & motu1246 \\
\hline Nakanai & naka1262 \\
\hline Ngkontar Ngkolmpu & ngka1235 \\
\hline Nobonob & nobo1238 \\
\hline North Tairora & nort 2920 \\
\hline Yawa & nucl1454 \\
\hline Kwerba & nucl1595 \\
\hline Marind & nucl1622 \\
\hline Oksapmin & oksa1245 \\
\hline Ormu & ormu1248 \\
\hline Pare & pare1271 \\
\hline Pinai-Hagahai & pina 1252 \\
\hline Serui-Laut & seru 1244 \\
\hline Sinaugoro & $\operatorname{sina} 1266$ \\
\hline Sinasina & $\operatorname{sina} 1271$ \\
\hline Suabo & suab1238 \\
\hline Suau & suau1242 \\
\hline Tabla & tabl1243 \\
\hline Tauade & taua1242 \\
\hline Telefol & tele1256 \\
\hline Tifal & tifa 1245 \\
\hline Waima & waim 1251 \\
\hline Wandamen & wand 1267 \\
\hline Wano & wano1243 \\
\hline Waritai & wari1264 \\
\hline Western Dani & west 2594 \\
\hline Yei & yeii1239 \\
\hline Yopno & yopn 1238 \\
\hline Zimakani & zima1244 \\
\hline
\end{tabular}


Extended Data Table 3 | The percentage of unique knowledge associated to threatened and non-threatened languages and plants. a, North America ( $n=$ 7,565 medicinal services); b, northwest Amazonia ( $n=773$ medicinal services); c, New Guinea ( $n=873$ medicinal services). Language threat follws the classification in the Ethnologue $^{23}$. Plant threat follows the IUCN Red List of Threatened species ${ }^{16}$.

A

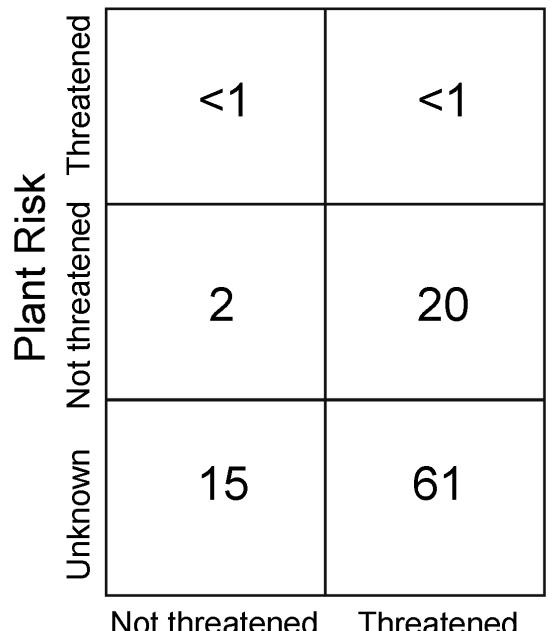

B

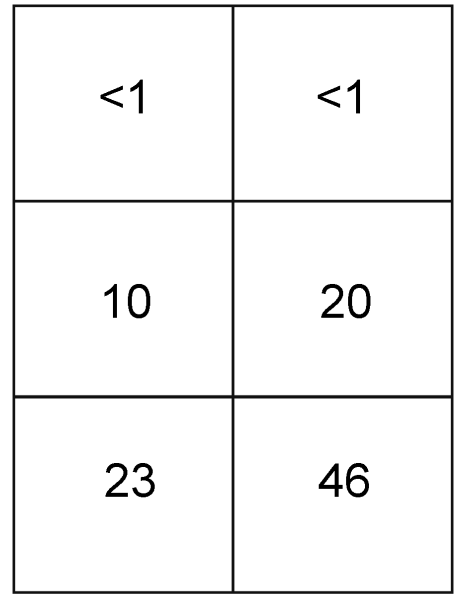

Not threatened Threatened
C

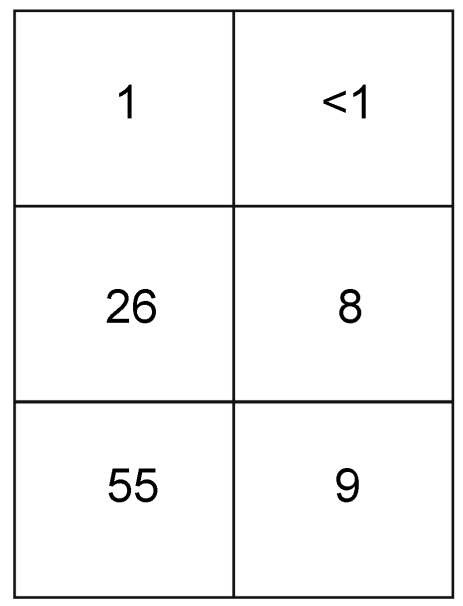

Not threatened Threatened 